\title{
Semantic Analysis of the Wa Tautology in Subordinate Clauses with Minimal Independence Degree
}

\author{
Liu $\mathrm{Yu}^{1, \mathrm{a}}$ and Zhao Junhuai ${ }^{2, \mathrm{~b}}$ \\ ${ }^{1}$ School of International Studies Jingdezhen Ceramic Institute Jingdezhen, China \\ ${ }^{2}$ School of Foreign Language Tianjin University of Science \& Technology Tianjin, China \\ azjh_Ix2072@hotmail.com, 'Iredfish_0@163.com
}

Keywords: Tautological Expression; Dependent Clauses; Contrastive Expression; Analogical Expression; Category

\begin{abstract}
Japanese boasts a great variety of tautological expressions, by which these tautologies fall into three categories indicated by particles, namely, 八(pronounced wa), ガ(pronounced ga) and モ (pronounced mo). Some of which carry certain unusual semantic features when these tautologies are employed in clauses. This paper aims at analyzing the 八(pronounced wa) tautology in subordinate clauses with minimal independence degree, and exploring the semantic properties of this category.
\end{abstract}

\section{Tautological Expressions Of ハ Class In Subordinate Clause}

Particle classification is used to classify Tautological expressions in this paper, which is to take particle of Tautological part as classify standard. Tautological expressions of 八 Class can be subclassified into four classes:

(1) 〜X1はX2(だ) 1

(2) X1はX2(で)、Y1は Y2(だ)

(3) X1 は X2でも〜

(4) X1 1 X2 で〜

This paper focuses on Type (4) whose language form can be expressed as X1 は X2 で〜[1]. For this form, the first question is which part of its Tautological expression belongs to. Type (4) is similar to Type (2), because the first half of Type (2) is also the form. But these two types are completely different. The following two examples can explain their differences from three aspects.

(1) 昔は昔、今は今。

(2) 冬は冬で日本海側は汽車が豪雪で立ち往生しているのに、太平洋側は空風が吹きまく る。

First, we can see that "で” of Type (2) is often omitted in daily dialogue. Even if it is not omitted, we can know that “で” is Middleton form of Auxiliary Verb “だ”, that is, it is an Auxiliary Verb. In Example (2) which represents Type (4), there is usually no dayton after "で”. Seeing from the sentence meaning, it is difficult to say that this "で” is an Auxiliary Verb and it should be taken as a Case-particle.

\footnotetext{
${ }^{1} \mathrm{X}_{1}$ and $\mathrm{X}_{2}$ refer to the same noun. The superscript is the sequence of the noun in a sentence. If the number is unnecessary, $\mathrm{X}$ is used to represent the noun of the Tautology part in this paper.
} 
Second, seeing from the sentence structure, the front part and the back part of Type (2) is called "等 位節” or “並列節”, which is tied clause. However, in Type (4), Tautological part is obviously not tied clause or main clause, so it is a clause sentence.

Third, from the overall translation of the sentence, they are different. Tautological expression will appear when Type (2) is translated into Chinese or English, while Type (4) will not.

(1a)以前(过去)是以前(过去), 现在是现在。

(1b)The past is the past, today is today.

(2a)冬天日本海那边火车因大雪而无法开动, 太平洋岸却猛刮干风。

(2b)When it comes to winter, trains get stuck in heavy snows along the coast of the Japan Sea when strong winds blow beside the Pacific Ocean.

From the underlining parts of Chinese and English translation of Type (1), it can be seen that Type (2) can be translated into Tautological expression without any problems, while Type (4) cannot.

Japanese clauses classification of Minami(1974) has been improved, this paper uses the classification of Noda (1996).

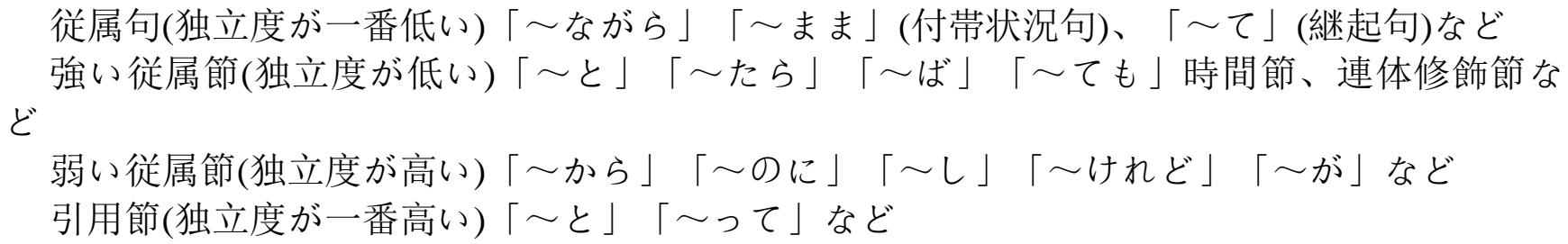

It can be seen from the above classification, Tautological part of Type (4) only belongs to subordinate clause (従属句) which has the lowest degree of independence. “従属句” has no definite Chinese translation. According to Japanese Linguistics, in a sentence, parts with “ながら” are called “従属節” which is clause. In linguistics, there are two translations for “句” of Japanese, which are "phrase” and “clause". Japanese grammar often uses it as the translation of the latter one, but "clause" also means “从 句”. So this is a problem of unequal concept caused by the differences of languages. Considering that there is less unit than phrase or clause in Chinese, this paper takes“小句”as the translation of “従属句” (“词组” is also possible, but it is too unnatural).

However, it should be noted that according to Noda(1996), in Subordinate Clause, neither “は” nor “が” can be used. From this point of view, only "X2 で” in Type (4) can be called Subordinate Clause, so the later part of Tautological express of Type (4) is in Subordinate Clause, which is different from Type (3). In Type (3), the whole Tautological expression is in Subordinate Clause. Although there is half in Subordinate Clause, Type (4) can be called "Tautological expression in Subordinate Clause".

\section{First Research of Type (4)}

Like Type (3), the first research of Type (4) is less. At first, it was carried out as a custom sentence by Chen Shengbao (1986) in Advanced Japanese for Grade Three of China. Example (2) in this paper is from this book. Chen Shengbao (1986) explains Type (4) as 
「冬は冬で」のように「名詞十は+同じ名詞十で」という表現は、「冬は冬にふさわしい 事情がある」とか、「冬は冬の問題点を持っている」などの意を表す。そして用言の場合だ と、「続けば続いたで」のように、「仮定表現十過去表現十で」というふうに使われる。

In fact, Type (4) is a more difficult to understand for Japanese learners from China, because it is a meaningless repetition literally in the sentence as a whole for Japanese learners from China. Chen Shengbao (1986) only superficially interprets Example (2). Whether it is for the understanding of Japanese learners or for the fundamental meaning of the meaning characteristics of Type (4), it is not very inadequate. On the basis of reference of Chen Shengbao (1986), the author summarizes for Japanese learners on Type (4).

XはXなりの事情・状況・方法・特性などがある。「はX2 で」という部分を「も」に換 えても意味はそれほど变わらない。

It was very important that "it can be replaced with particle "も”. It is useful for Japanese learners to understand Type (4), and it also reflects that Type (4) has the nature of contrastive sentence. The nature of being similar to contrastive sentence is proved in グループ・ジャマシイ(1998). According to グル ープ・ジャマシイ(1998): “「XはXで」と同じ名詞を繰り返し用いて、他のものと対比しなが らXについて述べるのに用いる。”By careful observation, it can be found that Type (2) (X1は $\mathrm{X} 2(て ゙)$ and Y1は Y2(だ)) is very similar to contrastive sentence in language form. But in the later discussion, it can be seen that they are not contrastive sentences. They should be called analogical sentences. The following Example (3) is a more complete example in language form.

(3) 夏は夏で溶けそうだ。冬は冬で眠い。

In this example, "summer" and "winter" are a pair of antonyms. The sentence is like a comparison between summer and winter. Okamoto (1991)(1993) also gives some examples which are similar to Example (3), which takes Type (4) as the sentence with the structure of the expression of contrast.

（4）私があれほど憧れ、狙っている一流会社の一流男。昼間は昼間で社内の女どものもの すごい争奪戦があり、夜は夜でホステスが鵜の目鷹の目。

(5) 平日はもういつでもものすごく混んでるし、ウィークエンドはウィークエンドでまた すごいの。

(6) 男の子は、なんてたって末が楽しみですよ。頼もしいものですよ。でも、娘は娘で可 愛いものですね。両方あるのが一番ですよ。

(The sentences of the three examples were written originally in Roman letters and were translated into Japanese for the convenience in this paper.)

\section{The Semantic Properties of Type (4)}

From the underlining parts of the above examples, it can be seen that there are a pair of antonyms or a pair of words which is similar to antonyms. This can be said to be a prerequisite or condition, only with this premise or condition, Type (4) can be used. Examples from グループ・ジャマシイ(1998) all have this feature.

(7) 彼の言うことなど気にせず、君は君で自分が正しいと思ったことをやればいいのだ。

（8）姉はオリンピックで金メダルを取り、妹は妹で、初めて書いた小説が芥川賞を受賞し 
た。

タヌキは若い女に化け、キツネはキツネで立派な侍に変わった。

It seems that Type (4) can be said to be an extension of Type (2). In order to better highlight this association, Example (3) can be modified.

(3a)夏は夏で、冬は冬だ。

(3b)夏は溶けそうだ。冬は眠い。

As shown in (3a), if the narrative part of the latter half is removed, Example (3) will immediately become Type (2). And (3b) shows a similarity to Type (3), that is, delete one of X, the sentence meaning roughly unchanged. This indicates that if Tautological parts of Tautology of 八 Class of Japanese is not the same part of the main clause, one $\mathrm{X}$ can be deleted to make Japanese learners better understand its characteristics. $\mathrm{X}$ is only different from Type (3). Type (3) achieves this effect by removing $\mathrm{X} 1$, and Type (4), by removing X2.

In addition, Type (4) has an important feature that the parts of two pairs of terms $\mathrm{X}$ and $\mathrm{Y}$ do not have to be symmetrical like Example (3), which is proved by Examples (5)-(9). X and Y even do not have to appear together. For example,

(10) (新しく開発されたソースをかけた料理について)

「おいしいんだろうけど、ソースはソースで食べたい。」

But even if one of $\mathrm{X}$ or $\mathrm{Y}$ does not appear, it does not mean there is no $\mathrm{X}$ or $\mathrm{Y}$. It is potential in another form. For example, $\mathrm{X}$ is “料理自体” in Example (10).

In other words, it can be concluded that there must be a pair of things in Type (4).

According to the example of Okamoto(1991), compare it with the original sentence after deleting X2, the argument can be proved.

(11) 野菜は野菜でここに置いて下さい。

(11a)野菜はここに置いて下さい。

(11a) is purely the expression of the meaning of the vegetables are here. The sentence is not about the following meanings, is there other things besides vegetables which will be put here? Should the things be put here or there? (11) is different. It has the following two meanings, such as “野菜は野菜、 野菜だけのグループにする” and”その野菜だけのグループをここに置く”. In other words, (11) is to have the meaning of the distinction or classification of things, which means (11) must contain “ほか の食材もある”. Therefore, in (11), vegetables and other ingredients are indispensable.

The follows are the most important feature of Type (4), which is also the key basis that determines that it is not contractive sentence.

Back to the previous summary of a key feature of Type (2), things represented by X and Y of Type (2) must have one thing in common to make this pair of things belong to the same category at a deeper level. From this critical summary and the similarity of Type (2) and Type (4), it is reasonable to deduce that Type 4 also has this characteristic. The key is how to demonstrate it.

After Example (5), Okamoto(1993) changed the sentence into:

(12)*平日はもういつもものすごく混んでるけど、ウィークエンドはウィークエンドでわり 
あいすいている。2

Okamoto (1993) makes this example a complete mistake by changing the narrative part of the “また すごいの” at the end of the sentence into “わりあいすいている”, which is similar to the opposite meaning of the narrative. Okamoto (1993) regards the things represented by X and Y of Type (4) as two contrastive frames, treating the narrative part of the situation as a consequence, from Example (5) and (12), it is deduced that the two frames of $\mathrm{X}$ and $\mathrm{Y}$ will bring the same consequence, and if not, " $\mathrm{X}$ は $\mathrm{X}$ で” is not applicable. This common point is not that $\mathrm{X}$ and $\mathrm{Y}$ have on literal meaning, it is the second half of the narrative part of the statement expressed. In addition to the above examples, there are more examples to support this.

(13)輝己がときどき加わる夕飯の時間も、朋子には楽しみだった。葡萄酒のことなら任せ てくれ、といら輝己の講釈を聞きながら、葡萄酒を飲み、食後は食後で、輝己がアルコール 分を炎にして抜いてくれたブランデーを嘗めた。(津島佑子 83)

(14) (権叔父に批判されて)本位田又八「やめたやめたっ。やってられっかっ。俺は俺でや っていく!!おふくろたちと一緒じやいつまでたっても俺は又八のままだ。俺は小次郎!佐々木 小次郎だっ!!」(井上雄彦(2001)『バガボンド 11』講談社)

(15)(トイレ中にアラレちゃんに吹っ飛ばされてたいへんに目にあった)則巻センベイ博士 「ボクちゃんあんなハジかいたのうまれてはじめてだいっ！！こ、このまえはこのまえで地 球をわってしまうし！！」(鳥山明(1995)『Dr.スランプ 2』集英社文庫 p185)

All of the examples listed above in this paper clearly show the common points between $\mathrm{X}$ and $\mathrm{Y}$ in the narrative of the second half.

(2)(3)夏と冬、両方とも人間に望ましくない状況。

(4)昼間と夜、両方とも女の激しい競争対象になっている。

(5)平日とウィークエンド、両方とも混雑している状況。

(6)むすことむすめ、両方とも親にとって望ましい側面を持つ。

(7)彼と君、両方とも自分が正しいと思っている意見がある。

(8)姉と妹、両方ともある程度の成功を収めている。

(9)タヌキとキツネ、両方とも立派に人間の姿に化けることができる。

(10)料理自体と料理に使うソース、両方ともおいしい。

(11)野菜とほかの食材、両方とも食材。

(13)食事中と食後、両方ともお酒を飲んだ。

(14)佐々木小次郎を装った又八と宮本武蔵、両方とも剣道修行を進んでいる。

(15)今回とこのまえ、両方ともアラレちゃんがひどいことをした。

It can be seen, the things represented by $\mathrm{X}$ and $\mathrm{Y}$ must have a common point which is also the necessary conditions of using Type (4).

However, Okamoto (1993) used the term "contrast" for X and Y, which is considered to be very inappropriate and needs to be specified. The concept of contrast (“対比表現”) is mentioned in many studies, however, there is not a clear definition. Many times it is roughly used in the following examples.

(16)野菜は好きだけど、肉は嫌いだ。

\footnotetext{
${ }^{2}$ The asterisk in front of the sentence means the sentence is completely wrong.
} 
(17)北海道？夏だったら行きたいけど、冬は行きたくないね。

To analyze the contrastive sentence and Tautological part of Type (4), the clauses where X and Y are must be divided into subject and narrative department. Contrastive sentence and Tautology of Type (4) have the same place that $\mathrm{X}$ and $\mathrm{Y}$ are opposite or relative. The key difference between Type 4 and contrastive sentence is the narrative part. Like (16) and (17) which are contrastive sentences, linguistic meaning of the narrative part is opposite or relative. While the narrative of Type (4) is similar, which is evident from the comparison of Examples (5) and (12). Comparison can be done of Example (10) and

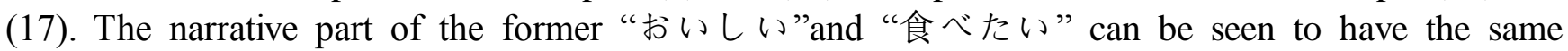
meaning. If someone thinks something is delicious, it means he wants to eat it. It is not the same although there is both the meaning of "going" of the narrative parts in (17). "Going" is the meaning of the fragment, not the overall significance of narrative parts.

Therefore, Type (4) is fundamentally different with the general contractive sentence. It is not appropriate to call it contrastive sentence. Perhaps it can be called analogical sentence.

Analogy which is carried out by the narrative part makes Type (4) have another important feature which is different from Type (2). Tautology of Type (2) is a kind of stress sentence. Since the main analogical meaning parts are in narrative part, Tautology of subject part of Type (4) has no stress role. In other words, Tautological expression of Type (4) disappears. It only plays a sub-category of the subject matter of the sub-category role and the function completely disappears.

Finally, there is an extremely important intermediate transitional example that fully shows the relevance of Type (4) and Type (2).

(18)ワムウ「なっ！なんの真似だ！？」

ジョジョ「おまえの首から出ている煙は爆発の煙ではない! ..... それは「波紋傷」の煙 だ！先に胸や脚にくらった「波紋」はすでに全身に回っていたようだな。おめ一らにとって 波紋がどんなに苦しいかはょく知っている。もうなおすことはできねえが、拉执の血で せめて痛みを和らげて死にな！」

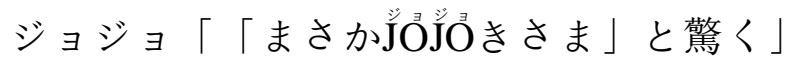

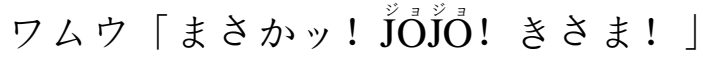

ジョジョ「そうさ! ワムウ! 戦いは戦いで別、シーザーの死の悲しみは悲しみで別...... お れもなぜかあんたに対して敬意をはらいたくなったのさ .....この血はあんたへの「敬意」な んだ.....」(荒木飛呂彦(2002)『ジョジョの奇妙な冒険 $7 』$ 集英社文庫 p152)

This example is almost identical in language to Type (2). Since there are other language components in Tautological part, it belongs to Type (4) from the perspective of sentence structure. It can be said that it is the intermediate transitional example of connection between the two types, which is relatively rare.

\section{Conclusion}

This paper makes a general analysis and summary of the characteristics to Tautology (Type (3)), where Tautological part is in clause. Several key points can be summarized as follows.

1) Tautological part appears in subordinate clauses with minimal independence degree. Only " $X_{2}$ で" is the subordinate clause.

2) Tautological part will not appear when translating into Chinese or English. 
3) It is similar to the semantic properties of Type (2) characteristics in some parts. There are a group of things in pairs in the whole context, representing the subject of the type. The subject matter of things can be symmetrical or asymmetric in the form of language, one of which sometimes does not appear literally.

4) Being significantly different from Type (2), its subject which is the Tautological part does no longer have the tone of emphasis, but is functional as the auxiliary role of a sub-category of the subject matter.

\section{References}

[1] グループ・ジャマシイ(1998)『教師と学習者のための日本語文型辞典』くろしお出版

[2] 野田尚史(1996)『「は」と「が」』くろしお出版

[3] 南不二男(1974)『現代日本語の構造』大修館書店

[4] Chen Shengbao, Hu Guowei, Chen Huahao (1986). Japanese (5th volume of high school professional textbook of University of Japanese). Shanghai Foreign Language Education Press.

[5] Zhai Dongna, Lin Hong, Pan Jun. Japanese Linguistics. 2006, Higher Education Press.

[6] Okamoto, shigeko, 1991. Nominal 'tautologies' in Japanese: $X$ wa $X, X$ ga X, X mo X. Proceedings of the 17th Annual Meeting of the Berkeley Linguistics Society, 218-229

[7] Okamoto, shigeko, 1993. Nominal repetitive constructions in Japanese: The 'tautology' controversy revisited. Journal of Pragmatics 20: 433-466 